\title{
TESTING THE COST ASSESSMENT METHODS APPLICATION AT A HOSPITAL FOR THE DECISION "MAKE OR BUY"
}

\author{
Venelin Terziev $^{\mathbf{1}}$ and Stoyanka Petkova - Georgieva ${ }^{2^{\star}}$ \\ ${ }^{1}$ Full Member of the Russian Academy of Natural History, Professor, Eng,
} D.Sc. (National Security), D.Sc. (Economics), D.Sc. (Social Activities), Ph.D., Russian Academy of Natural History, Moscow, Russia, Vasil Levski National Military University, Veliko Tarnovo, Bulgaria University of Rousse, Rousse, Bulgaria, terziev@skmat.com

${ }^{2}$ Associate Professor, Ph.D., University „Prof. d-r Assen Zlatarov” - Bourgas, Bulgaria, s.p.petkova@gmail.com

${ }^{*}$ Corresponding Author

\begin{abstract}
The subject of the article is to publish the results from experimental testing of the cost assessment methods and especially the possibility of their application at a hospital for the decision "makes or buys". The most important analyzed result is the impact of the decision "make or buy" on different kinds of costs that are common at the hospital activities. By this mean, there are considered four aspects of the decision - strategic, time duration, organizational and calculation. Two criteria assessment groups are presented - standard and additional as the second one report on the purchase time duration and on the preliminary and followed buying costs. There is shown up an assessment consistency for the single costs resulted from the process of starting an own production in different situations. This publication is the second part of the conducted research.
\end{abstract}

Keywords: cost assessment methods, hospital, decision "make or buy".

\section{INTRODUCTION}

One of the basic problems for the production and logistics management are how to define optimal limits for the activity of an enterprise. If we consider an organization that is in the health care business as an enterprise it means that we have to be very aware of the cost assessment methods application such as we are taking the responsibility for an enterprise (Petkova - Georgieva, 2018b, pp.71-77). The survival of the hospitals at dynamic market circumstances demands to focus on only those activities and processes which ensure them maximal competitiveness. This leads to limiting their variety as some of them are realized by other organizations in the health care business. For this reason, the hospital managers such as the managers of an ordinary enterprise have to solve a very important and complicated task about exactly which activities the hospital to keep and which to buy from outer organizations like the principle of outsourcing. These problems are known in the theory as the decision "make or buy".

The analysis of the different alternatives for proceeding from own production to outer activity buying demands two criteria groups assessment - qualitative and quantitative. The subject of the article is to present from a quantitative point of view the impact of the decision "make or buy" on all kinds of costs that are common for a hospital. 


\section{INVESTIGATION RESULTS}

For the assessment of the cost criteria about the decision "make or buy" assessment there are investigated four criterion assessments. The health care product unit costs determining at own production (cM) and at purchasing (cB) demand a detailed analyze of the possible consequences for the due alternative.

\subsection{Standard Criteria Assessment}

The two alternatives cost comparisons traditionally are peculiar during the time planned period. Usually, it is presumed that the firm capacity stays permanent and it doesn't change t.i. the short time duration of the planned period does not allow the fix costs to be adapted. In such situations as a decision assessment criterion are used the variable costs $(\mathrm{cV})$ per a production unit.

Criterion 1st: The purchase is economically beneficial if the market price $(\mathrm{cB})$ is lower than the variable costs (cV).

$\mathrm{cM}=\mathrm{cV}, \mathrm{cB}<\mathrm{cV}$

Using the above criteria, it is important to examine if the material deliveries are with long termed contracts, because in that case they cannot be terminated automatically (Nagar, 2014). Also, it must be considered that the purchased and stored materials and details are not good for the variable costs decreasing. The variable costs must be divided to the planned delivery amount. As a result, the effect per product unit is calculated.

Criterion 2nd: The purchase is economically beneficial if the market price $(\mathrm{cB})$ is lower than the total prime costs (cT).

$\mathrm{cM}=\mathrm{CT}, \mathrm{cB}<\mathrm{C} T$

If it is considered that the capacity is not fix and the time duration for the planned period is enough and it allows any corrections during the own production, then as an assessment criterion, there could be used the total prime costs (cT). In this case the fix indirect costs must be allocated among the considered decision object.

For the two criteria it is typical that the costs are assessed at two extreme capacity meanings when the planned period is the only restrictive parameter. Those criteria are proper only then when the expected term for purchasing is shorter than the shortest final term for including the assets used for decision object production (criterion 1), or longer than their longest final term (criterion 2).

The variable costs could be used like assessment criteria to the alternative "make or buy" when the purchasing term (suspending the appropriate production) does not exceed one month.

On the other hand, it is obvious that at the same cost centers there exists an extra resource that generate fix costs which shortening is possible for a period longer than a year. Here, the restriction is the planned period duration. If the production factor bind term is longer than the planned period ( $T p p<T b i n d)$ then the total prime cost cannot be used as assessment criteria. In this case the assessment criteria include the production costs that are between the short-term variable costs (cV) and the total costs (cT) that can be corrected in long term aspect. According to this base the third criterion is formed.

Criterion 3rd: The purchase is economically beneficial if the market price is lower then the variable sum and reducible fix costs per a product unit.

$\mathrm{cM}=\mathrm{cV}+\mathrm{cRF}, \mathrm{cRF}=\mathrm{cTC}-\mathrm{cNRF}$

$\mathrm{cB}<\mathrm{cV}+\mathrm{cRF}$

The own production costs that are accepted for an assessment criterion consist of variable cost per a product unit (cV) and restricted fix costs (cRF). The not restricted fix costs (cNRF) during the planned period usually include the central administrative costs for the general firm units like human resource, accounting planning departments, etc. also and calculate interest and extra equipment amortization, reserve devaluation and social costs for suspending from work (Bozova, 2017, pp. 58-62).

The amount of the real cost economy depends on several factors. The problem "to make or buy" demands the cost calculating system to be improved, as the impact of the next four factors must be considered:

1. The alternative "to make or buy" assessment moment, t.i. the planned period cost calculation. This moment also determines the impact of the second factor;

2. Time duration of the potential purchase, thence the duration of production sustention of a product unit. This causes factor 3 ; 
3. Final costs. They can be divided into two groups:

- costs by the production process specifics - for maintenance and preserving of the machines;

- human resource costs (for example paying compensations for suspending from work, etc.) and material resource costs (for example paying compensations for suspending delivery contracts)

4. Preliminary costs. Here are included the purchaser costs for the production preparing or providing of necessary production process quality from the deliverer.

\subsection{Extra Assessment Criteria}

The extra assessment criteria give an account of the planned period time duration, the time term for a purchase and the purchase final and preliminary costs.

The planned period time duration and the time purchase term are in correlation. While the planned period time duration determines the reducible fix cost amount, the time purchase term determines the one-time cost amount for suspension the production per product unit. Another factor that must be considered is the moment of calculation, which leads to forming a system of step by step planning.

Criterion $4^{\text {th: }}$ : The purchase is economically beneficial if the market price is lower than the variable and reducible fix cost sum minus the cost amount for suspension the production per product unit $\left(\mathrm{C}_{\mathrm{B}}<\mathrm{C}_{\mathrm{M}}\right)$.

$\mathrm{C}_{\mathrm{M}}=\mathrm{C}_{\mathrm{V}}+\mathrm{C}_{\mathrm{RF}}-\mathrm{C}_{\mathrm{CD}}$

$\mathrm{C}_{\mathrm{B}}<\mathrm{C}_{\mathrm{V}}+\mathrm{C}_{\mathrm{RF}}-\mathrm{C}_{\mathrm{CD}}$

It occurs that the cost amount for suspending the production depends on the opposite factors action that are with a temporary and quantitative character. As the purchase term is shorter the one-time cost amount for suspending the own production increases and the reducible fix cost amount decreases. The determining of economical optimal interval for suspending an own production demands calculation by separate periods Table. 1.

As a moment of making the calculations can be considered the interval $t=0$ (an interval that is before the planned period). Also, it can be considered that the decision for buying is taken for a period beginning with interval $t=1$. This means that at a decision for buying only for a month the delivery is only trough interval $t=$ 1 and when the supplying is for 12 months the purchase term is restricted between $t=1$ and $t=T=12$.

It can be seen from Table 1 that the purchases for a period from 1 to 5 months are not economically beneficial because of the possible own production cost savings per product unit that are negative as a result of the high unit costs levels for the production suspension (Terziev, Petkova-Georgieva, 2019e, pp.369-375). It can be generalized that the cost amount, which can be saved for different periods, depends on the reducible fix costs period thence it depends on the possible schedule terms for their reduction. On this base the critical purchase amount can be calculated $\left(Q_{B}\right)$.

$\mathrm{Q}_{\mathrm{B}}=\mathrm{C}_{\mathrm{CD}}:\left(\mathrm{C}_{\mathrm{M}}-\mathrm{C}_{\mathrm{B}}\right)$

If we accept that the own production suspension costs $\left(\mathrm{C}_{\mathrm{CD}}=300000 €\right)$ do not depend on the production duration and the market price $\left(C_{B}=15 €\right)$ and are permanent for all periods, the next critical purchase amount can be calculated. This is for outer delivery time duration process for 1 to 12 months (Table 2). Here it is important to notice that when we calculate the own cost amount $\left(\mathrm{c}_{\mathrm{M}}\right)$ which can be saved, there are not included the cost amount for suspension the production per product unit.

It is obvious from Table 2 that with the product costs equalization to the market price this resulted in unsteady increase of outer purchases critical amount. For example, at purchase time duration for 10 and 11 months the critical amount exceeds the annual necessities.

As we mentioned before, the moment of the conducted calculations has an extraordinary impact on the own production costs amount variables. Usually the cost amount for suspension the production per product unit could not be considered as meanwhile is not registered any changes for the planned parameters (Terziev, Petkova-Georgieva, 2019d, pp.361-368). 
IJASOS- International E-Journal of Advances in Social Sciences, Vol. VI, Issue 16, April 2020

Table.1. The possible saving costs calculation per own produced product unit at a variable interval for production suspension

\begin{tabular}{|c|c|c|c|}
\hline \multicolumn{4}{|c|}{ DECISION PARAMETERS } \\
\hline \multicolumn{2}{|c|}{ Moment of calculation: } & \multicolumn{2}{|c|}{$t=0$} \\
\hline \multicolumn{2}{|c|}{ Outsourcing: } & \multicolumn{2}{|c|}{1666 units per month } \\
\hline \multicolumn{2}{|c|}{ Maximum term of buying: } & \multicolumn{2}{|c|}{12 months } \\
\hline \multicolumn{2}{|c|}{ Moment of fixed costs reduction: } & \multicolumn{2}{|c|}{ At the beginning of the month: } \\
\hline Outsourcing for: & $\mathrm{C}_{V}+\mathrm{C}_{\mathrm{RF}}(€)$ & $\mathrm{C}_{\mathrm{CD}}(€)$ & $\mathrm{c}_{M}(€)$ \\
\hline 1 month & 8,00 & 180,00 & $-172,00$ \\
\hline 2 months & 8,00 & 90,00 & $-82,00$ \\
\hline 3 months & 8,00 & 60,00 & $-52,00$ \\
\hline 4 months & 8,00 & 45,00 & $-37,00$ \\
\hline 5 months & 8,00 & 36,00 & $-28,00$ \\
\hline 6 months & 48,00 & 30,00 & 18,00 \\
\hline 7 months & 42,75 & 25,71 & 17,04 \\
\hline 8 months & 39,25 & 22,50 & 16,75 \\
\hline 9 months & 34,25 & 20,00 & 14,25 \\
\hline 10 months & 28,55 & 18,00 & 10,55 \\
\hline 11 months & 26,30 & 16,36 & 9,94 \\
\hline 12 months & 48,00 & 15,00 & 33,00 \\
\hline
\end{tabular}

Table. 2. Assessment of the delivery critical amount at variable time duration of a suspension production term

\begin{tabular}{|c|c|}
\hline Outsourcing for: & Critical outsourcing amount $-\mathbf{Q}_{\mathrm{B}}$ units \\
\hline from 1 to 5 months & Negative, the outsourcing is not beneficial \\
\hline 6 months & 9090 \\
\hline 7 months & 10810 \\
\hline 8 months & 12371 \\
\hline 9 months & 15584 \\
\hline 10 months & 22140 \\
\hline 11 months & 26548 \\
\hline 12 months & 9090 \\
\hline
\end{tabular}


Using the data from table 1 we will consider that the moment of conducting the calculations from period 4 and further is $t=3$, but not $t=0$. This much impacts on per unit costs because from $t=4$ there is conducted a new accumulation of the planned necessity amount (the basic period $t=4$ has 1666 units). Also, the produced amounts between the first and third period do not impact on the taken decision. Then we can consider that the cost amounts for suspension the production per product unit like so far are $300000 €$. In this case we have the next alternative calculations (Table 3 ).

Table 3. The possible cost economy per product unit calculation at variable interval for production suspension and at an alternative calculation moment

\begin{tabular}{|c|c|c|c|}
\hline \multicolumn{4}{|c|}{ DECISION PARAMETERS } \\
\hline \multirow{3}{*}{\multicolumn{2}{|c|}{$\begin{array}{l}\text { Moment of calculation: } \\
\text { Outsourcing: } \\
\text { Maximum term of buying: }\end{array}$}} & \multirow{3}{*}{\multicolumn{2}{|c|}{$\begin{array}{c}\mathrm{t}=3 \\
1666 \text { units per month } \\
12 \text { months }\end{array}$}} \\
\hline & & & \\
\hline & & & \\
\hline \multicolumn{2}{|c|}{ Moment of fixed costs reduction: } & \multicolumn{2}{|c|}{ At the beginning of the month: } \\
\hline Outsourcing for : & $c_{V}+c_{R F}(€)$ & $\mathrm{C}_{\mathrm{CD}}(€)$ & $\mathrm{C}_{\mathrm{M}}(€)$ \\
\hline 1 month & 8,00 & 180,00 & $-172,00$ \\
\hline 2 months & 8,00 & 90,00 & $-82,00$ \\
\hline 3 months & 110,00 & 60,00 & 50,00 \\
\hline 4 months & 85,00 & 45,00 & 40,00 \\
\hline 5 months & 72,75 & 36,00 & 36,25 \\
\hline 6 months & 65,25 & 30,00 & 35,25 \\
\hline 7 months & 54,75 & 25,71 & 29,04 \\
\hline 8 months & 42,55 & 22,50 & 20,05 \\
\hline 9 months & 102,25 & 20,00 & 82,25 \\
\hline 10 months & 88,55 & 18,00 & 70,55 \\
\hline 11 months & 76,30 & 16,36 & 60,94 \\
\hline 12 months & 68,00 & 15,00 & 53,00 \\
\hline
\end{tabular}

It can be seen from Table 3 that when we pay attention at the cost amount for suspension the production per product unit and the purchasing term exceeds three months, as a result there is a cost economy per product unit. Also, there is as a result an impact on the critical purchase amount (Simeonov, 2019f, pp. 2029- 2033; Simeonov, 2019g, pp. 943-945; Simeonov, 2019h, pp. 969-972; Simeonov, 2019i, pp. 987-988).

So far, we represented only the possible own production sunk cost t.i those costs that resulted from production suspension. At long term purchase decisions there must be considered also the appearance of preliminary costs which are connected with the supplying (CBB). They appear when the buyer and the seller act together in other to guarantee any special characteristics for the purchase object, which are analogous to the own production and the deliveries will be realized according to the necessary conditions (Terziev, Petkova-Georgieva, 2019b, pp.515-524; Petrova, Petrov, 2019a, pp.29-40). Those preliminary costs are represented as investments in the supplying process. They are caused by the buyer and have to be calculated by the alternative "buy". They impact on the supplying price per product unit like an allowance. On 
this base the next criterion is made:

Criterion 5th: The purchase is economically beneficial if the market price plus the preliminary costs are lower than the sum of the variable and the reducible fixed costs minus the cost amount for suspension the production per product unit.

$\mathrm{CB}+\mathrm{CBB}<\mathrm{CV}+\mathrm{CRF}-\mathrm{CCD}$

The preliminary costs (CBB) and the cost amount for suspension the production per product unit (CCD) must be divided to the total purchase amount during the planned buying period, so that the unit costs to be calculated. If $\mathrm{CV}=\mathrm{CCD}$ then the two impacts are neutralized and there can be used criterion 3rd. That correlation could be summarized by the next way. In both cases the buyer costs increase. The cost amount for suspension the production per product unit decrease the possible economy at a denial of own production, while the preliminary costs increase those costs which are as a result of outer delivery (Terziev, PetkovaGeorgieva, 2019d, pp.361-368; Petrov, 2019a, pp. 506-518; Petrova, Petrov, 2018c, pp. 213-228).

There must be considered and other aspect of the decision assessment "make or buy" connected with the level of capacity utility t.i. whether the hospital capacity will be at $100 \%$ at work or whether the planned requirement amount requires the whole organizational equipment. Thence the wrong thesis that at partial using capacity this will lead to a different meaning of the own production unit costs because of the little make capacity. The economical point of view of the decision "make or buy" is mostly oriented to the possible saving costs. Here must be considered that the structure and the amount of the reducible fixed costs are mostly determined by the contracts, but not by the level using the capacity utility. This is so, because of the fixed costs total amount does not depend on the using capacity equipment.

This is valid and to the quantitative aspect of the decision "make or buy". The planned amount impacts on the decision.

The level of using the capacity utility is of an interest from an economic point of view, only when there is an alternative for proceeding to own production, t.i. whether it is possible any own production of the buying so far products.

\subsection{Assessment Criteria for Own Production}

The decisions "make or buy" analyze demands to consider and the other alternative: "Is it economically beneficial to start an own production of an article that used to be delivered from other hospitals or business organizations?". On fig. 1 is represented an algorithm for unit costs assessment at different situations for starting an own production.

The standard situation $c_{I S}=c_{V}$ is not represented on fig. 1. This could be explained with the followed notes: On the one hand the technological development during the last years is characterized with much stronger transforming of the variables into fixed costs (Milgrom, Roberts, 2015). As a result, the fixed costs will content the variable costs. This means that the cost information is not lost. On the other hand, only, those fixed costs are considered which can be calculated directly to any object. The due unit costs can be calculated by balancing.

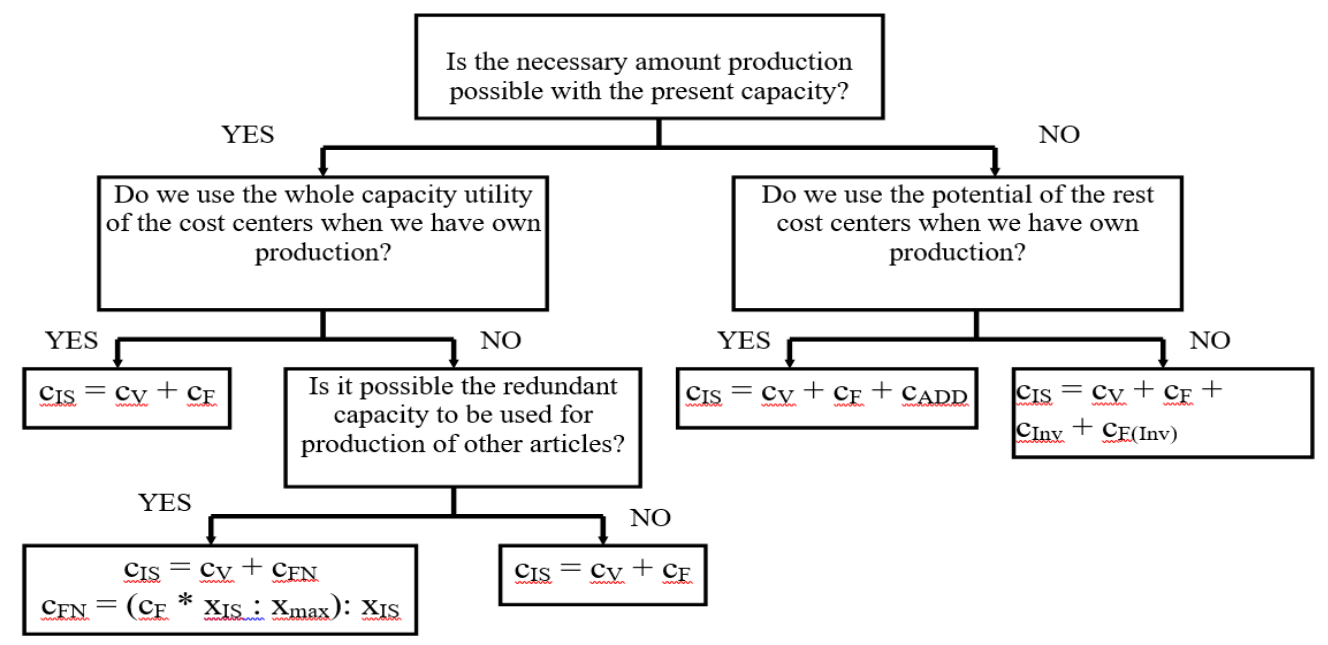

Fig. 1. Steps for direct (unit) costs assessment at own production. 
If the potential of the due cost centers is enough to supply the amount necessity than the unit costs for own production $\left(\mathrm{C}_{\mathrm{IS}}\right)$ are consisted of variable costs $\left(\mathrm{C}_{\mathrm{V}}\right)$ and the necessary fixed costs $\left(\mathrm{C}_{\mathrm{FN}}\right)$. The total prime costs per product unit could be used as a proper assessment decision criterion when the redundant capacity cannot be used for other activities (Milgrom, Roberts, 2016). This is typical only for those cost centers that are responsible for the due article. In the rest cases for the article must be used the specific variable costs and the calculated fixed costs - for example using the method Activity based Coasting.

\section{CONCLUSION}

The experimental testing of the cost assessment methods and especially the possibility of their application at a hospital for the decision "make or buy" is not a very easy task to solve. Also, it is not very common for hospital managers to use and apply the cost assessment methods in order to improve the hospital's better profit results. When there is insufficiency in the production potential (capacity utility), there must be verified two alternatives. The first one is to assess whether other hospitals (organization) units could cooperate for overcoming the bottlenecks. There might appear some extra costs - cADD that might help to choose the alternative "make".

The second alternative is a capacity extension. Two more elements must be added to the variable and the fixed costs:

1. The additional per product unit investment costs (clnv). The costs for buying new equipment and for new appointed workers must be divided to the necessity amount that is foreseen for the planned period.

2. The current fixed costs (for example salaries) which arise out of the investment into additional capacities. They must be divided to the necessity amount for the due planned period $(\mathrm{cF}(\operatorname{Inv}))$.

The tested cost assessment methods application at a hospital leads to a conclusion that it is a very useful possibility for the hospital managers to include in their activities the experiences of such methods, because it will improve the hospital profit results as a whole.

The published results are continued and this publication is the second part of the conducted research.

\section{REFERENCE LIST}

Bozova, G., (2017). Meditcinska grija za korabokrushentci. // Aviation, maritime and space medicine, 2017/2, pp. 58-62, ISSN 1314-5819.

Bozova, G., (2018a). Marariya - profilaktika I lechenie za korabniya sastav i pasajerite. // Aviation, maritime and space medicine, 2018/2, pp. 47-53, ISSN 1314-5819.

Milgrom, P., Roberts J., (2016). Economics, Organization and Management, Prentice-Hall, Upper-Saddle River, NJ 2016.

Milgrom, P., Roberts, J., (2015). Complementarities and Fit: Strategy, Structure and Organizational Change in Manufacturing, Journal of Accounting and Economics, 19, 2015.

Nagar, V., (2014). Interrelations Among a Firm's Delegation and Incentive Compensation Choices, WP, University of Michigan Business School, 2014.

Petkova - Georgieva, St., (2018b). Basic Problems to Solve in Strategic Controlling Implementation, annual of "Prof. Dr. Assen Zlatarov", pp. 71 - 77, v. XLVII, book 2, Burgas, Bulgaria, 2018, ISSN 2603-3976.

Petrov, Zhivo (2019a), Key Aspects and Analisys of European Defense Planning Processes, Proceedings of SOCIOINT 2019- 5th International Conference on Advances in Education and Social Sciences 21-23 October, 2019 - Istanbul, Turkey, pp. 506-518, ISBN 978-605-82433-7-8

Petrova T., Petrov Zh., (2018c), Modelling the Distribution of Lasers in Biological Tissues, Int J Bioautomation, 22 (3), 213-228, doi: 10.7546/ijba.2018.22.3.213-228

Petrova T., Petrov Zh., (2019a), Peculiarities in the Distribution of Temperature under the Influence of a Laser Beam in a Multilayered Medium, Int J Bioautomation, 23 (1), 29-40, doi: 10.7546/ijba.2019.23.1.29-40

Terziev, V., Petkova - Georgieva, S. (2019b). The performance measurment system key indicators and the determinants impact on the level of decentralization using as an example a subdivisional unit from the 
Bulgarian social health and care experience. // Proceedings of SOCIOINT 2019-6th International Conference on Education, Social Sciences and Humanities 24-26 June 2019- Istanbul, Turkey, International Organization Center of Academic Research, Istanbul, Turkey, 2019, pp. 515-524, ISBN: 978-605-82433-6-1

Terziev, V., Petkova - Georgieva, S. (2019c). A research study of nonlinearity experiencing in the rate of current account deficit to the Bulgarian health and care national product. // Proceedings of SOCIOINT 2019- 6th International Conference on Education, Social Sciences and Humanities 24-26 June 2019Istanbul, Turkey, International Organization Center of Academic Research, Istanbul, Turkey, 2019, pp. 525-533, ISBN: 978-605-82433-6-1.

Terziev, V., Petkova- Georgieva, S. (2019b). The level of decentralization impact on the Bulgarian social health care competitiveness. // Proceedings of ADVED 2019 - 5th International Conference on Advances in Education and Social Sciences, International Organization Center of Academic Research "Ocerint Publishing", Istanbul, Turkey,m 2019, pp. 361 - 368, ISBN: 978-605-82433-7-8.

Terziev, V., Petkova- Georgieva, S. (2019e). The Bulgarian health care system practical research on the usefulness of the performance measurement system. // Proceedings of ADVED 2019 - 5th International Conference on Advances in Education and Social Sciences, International Organization Center of Academic Research “Ocerint Publishing”, Istanbul, Turkey, 2019, pp. 369 - 375, ISBN: $978-$ 605-82433-7-8.

Simeonov, Simeon. (2019f). Diagnose with "Mirizzi Syndrome". // 21 st International scientific conference: The teacher of the future, Budva, Montenegro, (07-09.06.2019), Institute of knowledge management Skopje, Macedonia, 31, 2019, 6, pp. 2029- 2033, ISSN 1857-923X (for e-version), ISSN 2545 - 4439 (for printed version).

Simeonov, Simeon. (2019g). VATS-Method of choice in traumatic hemothorax. // XXII International Scientific Conference: The power of knowledge (11-13.10.2019), Kavala, Greece, Institute of Knowledge Management, Skopje, 34, 2019, 4, pp. 943-945, ISSN 1857-923X (for e-version), ISSN 2545 - 4439 (for printed version).

Simeonov, Simeon. (2019h). Complications in severe acute cholangitis. // XXII International Scientific Conference: The power of knowledge (11-13.10.2019), Kavala, Greece, Institute of Knowledge Management, Skopje, 34, 2019, 4, pp. 969-972, ISSN 1857-923X (for e-version), ISSN 2545 - 4439 (for printed version).

Simeonov, Simeon. (2019i). Transanal endoscopic microsurgery (TEM) and NOTES. Pros and cons NOTES. // XXII International Scientific Conference: The power of knowledge (11-13.10.2019), Kavala, Greece, Institute of Knowledge Management, Skopje, 34, 2019, 4, pp. 987-988, ISSN 1857-923X (for eversion), ISSN 2545 - 4439 (for printed version). 